пособ. для студентов пед. ин-тов] / под ред. В. Д. Шадрикова. М. : Просвещение, 1990. - 142 с. 12. Скаткин М. Н. Активизация познавательной деятельности учащихся в обучении / М. Н. Скаткин. - - М. : Педагогика, $1965 . \quad$ - 175 с. 13. Тарнопольский О. Б. Методика обучения английскому языку на 1 курсе технического вуза / О. Б. Тарнопольский. - К. : Вища школа, 1989. - 158 с. 14. Философский словарь / под ред. М. М. Розенталя. - [3-е изд.]. - М. : Политиздат, 1975. - 496 с.

Г. В. Даниліна, кандидат техн. наук, доцент, Криворізький коледж Національного авіаційного університету

\title{
ФОРМУВАННЯ У СТУДЕНТІВ ТЕХНІЧНИХ СПЕЦАЛЬНОСТЕЙ ПРИЙОМІВ НАВЧАЛЬНОӤ ДІЯЛЬНОСТІ ПІД ЧАС ВИВЧЕННЯ МАТЕМАТИКИ
}

У статті конкретизовано сутність поняття «прийом навчальної діяльності»; подано зміст, класифікачії, иляхи й засоби, наявні методи формування у студентів технічних спеціальностей прийомів навчальної діяльності під час вивчення математики.

Ключові слова: прийом навчальної діяльності, алгоритм, евристична схема.

В статье конкретизируется сущность понятия «прием учебной деятельности»; подается содержание, классификации, пути и средства, существующие методы формирования у студентов технических специальностей приемов учебной деятельности при изучении математики.

Ключевые слова: прием учебной деятельности, алгоритм, эвристическая схема.

In article the essence of concept «reception of educational activity» is concretized; the content, classifications, ways and the means, existing methods of formation at students of technical specialities of receptions of educational activity moves at mathematics studying.

Key words: reception of educational activity, algorithm, the heuristic scheme.

Курс математики для студентів технічних спеціальностей відіграє одну 3 провідних ролей у професійній підготовці. Цьому аспекту приділено належну увагу в концепції змісту вищої освіти (В. Андрущенко, Р. Гуревич, І. Зязюн, I. Козловська, В. Кремень, Н. Ничкало, С. Сисоєва та ін.); методиці навчання математики студентів різних спеціальностей (I. Акуленко, М. Башмаков, В. Бевз, Г. Бевз, О. Глобін, Н. Глузман, В. Гусєв, Г. Дорофєєв, Ю. Колягін, Т. Крилова, Д. Пойя, Г. Саранцев, С. Семенець, О. Скафа, 3. Слєпкань, Н. Тарасенкова, В. Таточенко, Т. Хмара, В. Швець та ін.). 
Установлено, що сформовані прийоми навчальної діяльності дозволяють студенту оптимально й ефективно засвоювати професійно важливі знання, компетентно організовувати власну діяльність, дізнаватися досліджуваних об'єктів усебічно й системно, що в подальшому створює підгрунтя для їх ефективної професійної діяльності (Ю. Бабанський, В. Буряк, В. Давидов, Д. Ельконін, Є. Кабанова-Меллер, Н. Менчинська, В. Паламарчук, А. Усова, І. Якиманська та ін.). На жаль, більшість педагогів-практиків стверджують, що сам процес навчання математики розвиває мислення. Цю думку свого часу спростовував С. Рубінштейн, який указував на неправомірність підпорядкування проблеми розвитку мислення проблемі засвоєння знань. Кожна із них має самостійне значення та свій шлях реалізації [3].

Mema cmammi - здійснити огляд основного змісту, класифікації, шляхів і засобів, наявних методів формування у студентів технічних спеціальностей прийомів начальної діяльності у вивченні математики.

У сучасній науковій літературі відсутнє єдине визначення поняття «прийом навчальної діяльності», хоч під час описунавчальної діяльності застосовуються поняття «дія», «операція», «прийом», «уміння», «навичка».

Дією називають процес, що підкорений свідомій меті, за допомогою якого здійснюється діяльність. Дії, що становлять основу навчальної діяльності, бувають трьох видів. Поперше, це ті, що є підгрунтям пізнавальної та дослідницької навчальної діяльності - аналіз, синтез, узагальнення, класифікація та ін., без яких ніяка діяльність неможлива. По-друге, це знакові, мовні, мовленнєві, вербальні засоби, у формі яких засвоюються знання, відтворюється індивідуальний досвід. По-третє, це фонові знання, за допомогою яких структурується індивідуальний досвід, тезаурус студента. Дії здійснюються тими чи іншими способами, тобто за допомогою певних операцій. Сукупність певних операцій, способи здійснення дій називають прийомом діяльності. Свідоме володіння яким-небудь прийомом діяльності називається вмінням. Уміння, доведене до реально можливого автоматизму, характеризується вже як навичка [2].

Кожна навчальна дисципліна розкриває в об'єктах і явищах певну групу ознак і властивостей, досліджує їх своїми специфічними методами та прийомами. Саме вони трансформуються в уміння, які й обслуговують певний предмет. До 
основних об'єктів засвоєння курсу математики належать: поняття, математичні факти (аксіоми, теореми, формули, співвідношення) та способи діяльності (правила, алгоритми, способи розв'язування задач і доведення математичних тверджень), для фіксації яких у зовнішньому плані використовуються вербальні та невербальні знаково-символічні засоби [4].

Ю. Бабанський, П. Блонський, Є. Кабанова-Меллер, Н. Менчинська та ін. під прийомом розуміють систему дій, які слугують для розв'язання навчальних завдань, і є виявленням рівня сформованості в суб'єктів умінь. Різні прийоми складаються зі значних чи менших систем дій і використовуються для розв'язання різного кола завдань [5].

У змісті прийому виокремлюють структурні елементи: предмет (сукупність тих об'єктів, до яких можна застосувати прийом), мета (результат, на досягнення якого спрямований прийом), операціональний склад (послідовність дій, або операцій, спрямованих на досягнення мети прийому).

Н. Тализіна виокремлює логічну й специфічну частини прийому. Логічним компонентом $є$ витримана структура прийому, алгоритм дії, що відповідає певній логічній структурі й логічні правила, використовувані при контролі правильності отриманих результатів. Специфічна частина прийому залежить від конкретного матеріалу, на якому виконується прийом (наприклад, способи розв'язання математичної задачі 3 різних розділів). Між логічною та специфічною частинами прийому наявний тісний взаємозв'язок, тому що прийоми найчастіше конкретні, а їх специфічний зміст може бути повноцінно засвоєно тільки в певній логічній системі [5].

Прийоми навчальної діяльності можуть бути різного рівня складності й узагальненості. Складний прийом містить у собі як складові дій інші прийоми $є$ необхідним для розв'язання більш складних завдань. Один узагальнений прийом замінює кілька часткових, створює орієнтовну основу діяльності для 3'ясування цілого класу навчальних завдань, є основою переносу на інші завдання [1]. До узагальнених навчальних прийомів у вивченні математики належать: 1) «підведення під ... (поняття, факт, спосіб діяльності)»; 2) «виведення наслідків», коли 3 відомостей про належність предмета до поняття (або про те, що дане співвідношення є конкретизацією математичного твердження, а дана послідовність дій - конкретизацією математичного правила) робиться висновок щодо наявності у 
даного предмета (співвідношення, послідовності дій) усіх властивостей даного поняття (математичного твердження, математичного правила) [4].

Зазвичай усі прийоми навчальної діяльності можуть бути класифіковані на: загальнонавчальні; розумової діяльності, загальноматематичні й спеціальні, які у свою чергу, залежно від рівня узагальнення, ступеня складності й способу перебігу можуть бути розділеними на - зовнішні, внутрішні, часткові й узагальнені (Ю. Бабанський, Д. Зайцев, Є. КабановаМеллер, Н. Менчинська, Н. Тализіна, А. Усова) [5].

Загальнонавчальні прийоми: слухання, спостереження, вимірювання, переписування, зарисовування й анотування, прийоми роботи 3 книгою, таблицями, комп'ютером, схемами; самоконтролю, організації навчального спілкування, позааудиторної роботи тощо.

Розумової діяльності: аналізу, узагальнення, конкретизації, встановлення причинно-наслідкових зв'язків, моделювання, побудови гіпотез; зосередження уваги, запам'ятовування; оперування поняттями, словесного опису, пояснення, формулювання проблем; самостійного здобуття знань.

Загальноматематичні: прийняття навчальної задачі; аналітико-синтетичного пошуку розв'язання, формування загального способу рішення, побудови системи підзадач, встановлення відповідності отриманих результатів даним, перевірки розв'язанням задачі різними способами, оцінки результату.

Спеціальні: прийоми розв'язання алгебраїчних, геометричних, стереометричних задач, побудови зображень тощо.

Кожен із прийомів навчальної діяльності складається з переліку конкретних дій, що дозволяє розв'язати те чи інше навчальне завдання. Виходячи з цього, прийоми можуть бути об'єктивно виражені описом, правилом, інструкцією, вказівками (у письмовому або усному вигляді) [2]. Показником сформованості прийомів навчальної діяльності є усвідомлення студентами змісту прийомів, здатність розповісти про його склад, обгрунтувати, аргументувати правильність його виконання [5], а також самостійно застосувати під час розв'язання завдань.

С два шляхи засвоєння прийомів навчальної діяльності: стихійний і керований. У першому випадку ці прийоми не $\epsilon$ предметом спеціального вивчення, їхнє формування відбувається в процесі засвоєння знань; при цьому вони не завжди 
усвідомлюються й, отже, часто не приводять до бажаного результату. У другому випадку прийоми слугують предметом спеціального засвоєння. Тоді різко скорочується процес їхнього формування, у результаті чого студенти здатні виконувати завдання більш якісно й ефективно, опановувати засобами самоосвіти [2].

У літературі розроблено поетапний шлях формування прийомів [2].
I eman.
Уведення
прийому
(способу
diü):

1. Характеристика прийому. 2. Опис дій, що входять до складу прийому. 3. Виконання дій викладачем.

На цьому етапі доцільним $є$ подання студентам алгоритму дій і виконання ними вправ за зразком.

II етап. Закріплення способу дій: 4. Виконання студентами дій, що складають зміст прийому, через систему навчальних завдань.

III етап. Навчання перенесення засвосних дій: 5. Перенесення на новий об'єкт. Перенесенням прийомів називається їх використання в нових умовах. Процес перенесення - це зіставлення вимог контрольного (нового) і навчального завдань. Широта перенесення - це коло завдань, на яке переноситься прийом [5].

Третій етап формування прийомів - складний вид творчої діяльності. Він потребує часу й копіткої роботи як викладача, так і студента.

На основі аналізу змісту й структури навчальної діяльності студентів у навчанні математики, було встановлено, що прийоми навчальної діяльності повинні становити систему, адекватну системі досліджуваного матеріалу, до якої висуваються такі вимоги: послідовність, цілісність, системність, нарощування складності й самостійності дій студентів, охоплення змісту всього навчального матеріалу, загальнонавчальних, розумових і математичних складових прийомів навчальної діяльності, передбачати специфіку майбутньої професійної діяльності, включати контекстні й професійно орієнтовані задачі.

Для ефективного формування прийомів може бути застосована евристична схема, що сприяє пошуку розв'язання найбільш розповсюджених математичних завдань: 1. Прочитайте завдання. 2. Виокремте умову й вимоги завдання, запишіть їх, зробіть малюнок чи схему. 3. Замініть терміни, що містить умова завдання, визначенням понять, які 
вони позначають, або їхніми ознаками. 4. За необхідністю замініть умову на рівнозначну (наприклад, у векторній, координатній формі). 5. Установіть ті положення, із яких виходять вимоги завдання. 6. Прочитайте ще раз умову й відповідно до співвідношень, із яких виходять вимоги завдання, оберіть одне з них. 7. Виявіть інформацію, що безпосередньо міститься в умові. 8. Намагайтеся 3 отриманої інформації одержати нову інформацію, і так доти, доки не здійсните «поєднання» отриманої інформації з положенням, прийнятим у п. 6. 9. Якщо обраний шлях не зумовив успіх, то розглянете інший шлях, «ідучи» по ньому до «поєднання» 3 новим положенням п. 5. 10. Продовжуйте розглядати можливі шляхи доти, поки не прийдете до одного 3 положень п. 5 [1]. Ця схема не тільки спрямовує процес пошуку розв'язання завдання, але і є джерелом самостійних узагальнень студентів.

Отже, прийомом навчальної діяльності є найбільш раціональна сукупність дій і операцій, виконуваних у певному порядку й така, що дозволяє розв'язати навчальне завдання. Склад прийому - схема дій або операцій, яка може бути представленою у вигляді правила, інструкції, припису, що складається із загальнологічної і специфічної частини прийому.

У психолого-педагогічній літературі сформульовано загальні принципи і шляхи формування прийомів навчальної діяльності. Для успішного їх упровадження необхідною є робота психологів, дидактів і методистів. Результатом такої роботи повинні бути дидактичні комплекси, що містять програми формування прийомів, методичні рекомендації для викладачів і навчально-методичні посібники для студентів.

\section{Література}

1. Давыдов В. В. Теория развивающего обучения / Василий Васильевич Давыдов. - М. : ИНТОР, 1996. - 544 с. 2. Платонов К. К. Краткий словарь системы психологических понятий / Константин Константинович Платонов. - М. : Высшая школа, 1981. - 174 с. 3. Рубинштейн С. Л. Основы общей психологии / Сергей Львович Рубинштейн. - СПб. : Питер, 2003. - 720 с. 4. Сердюк 3. О. Формування деяких розумових дій у процесі вивчення математичних понять / 3. О. Сердюк // Дидактика математики: Проблеми і дослідження : [міжнар. зб. наук. робіт]. - Донецьк, 2008. - Вип. 29. С. 95-99. 5. Талызина Н. Ф. Деятельностный подход к механизмам обобщения / Н. Ф. Талызина // Вопросы психологии. - 2001. №3. - C. 3-16. 